Мила Драгић

(Филозофски факултет, Нови Сад)
Изворни научни рад

УДК 811.163.41'373.74

DOI 10.19090/ppj.2020.51.115-131

\title{
МОРФОСИНТАКСИЧКЕ ОСОБИНЕ ФРАЗЕОЛОГИЗАМА РЕЛИГИЈСКОГ ПОРЕКЛА У САВРЕМЕНОМ СРПСКОМ ЈЕЗИКУ ${ }^{1}$
}

\section{САЖЕТАК}

У раду се испитују морфосинтаксичке карактеристике фразеологизама стандардног српског језика религијског порекла, те компатибилност њихове форме, значења и синтаксичке функције при употреби у текстовима публицистичког стила. Корпус чини око 50 фразеологизама религијског порекла и различитих значења, прикупљених уз помоћ стручне литературе и релевантних фразеолошких речника, док су примери употребе ексцерпирани из електронских издања дневних новина Политика и Политикиних чланака у електронском Корпусу савременог српског језика SrpKorp2013 Математичког факултета у Београду. Фразеологизми су груписани према структури и по бројности доминира група са структуром именичке конструкције, док је закључено да се издвојене јединице махом користе у синтаксичким позицијама које одговарају њиховим формалним (и семантичким) својствима.

КљУЧНЕ РЕЧИ: фразеологија, фразеологизми, религијско порекло, морфосинтакса, структура, функција.

\section{1. Увод}

\section{1. Предмет рада и корпус}

Предмет овог рада су морфосинтаксичке карактеристике фразеологизама стандардног српског језика који имају религијско порекло и њихова употреба у савременом језику медија. У одабиру фразеологизама пошло се од монографије Зашто се каже? М. Шипке (2010), у којој су издвојени

1 Овај рад настао је у оквиру пројекта Стандардни српски језик: синтаксичка, семантичка и прагматичка истраживања, који финансира Министарство просвете и науке Републике Србије (број пројекта 178004). 
фразеологизми религијског порекла, чак и ако немају експлицирану религијску компоненту у свом саставу, а коришћени су и Фразеолошки рјечник хрватскога или српског језика Јосипа Матешића, Фразеолошки речник српског језика Ђорђа Оташевића, Речник српскохрватскога књижевног језика Матице српске и Речник српскохрватског књижевног и народног језика САНУ. ${ }^{2}$ Испитано је око 50 фразеологизама религијског порекла, који су потом тражени у корпусу новинских текстова. Коришћена су електронска издања дневних новина Политика (Politika Online) пронађена на интернету, као и одломци пронађени у електронском Корпусу савременог српског језика SrpKогр2013 Математичког факултета Универзитета у Београду. Фразеологизми су у раду анализирани с аспекта морфосинтаксичких карактеристика њихових конституената, али и израза као целине, те компатибилности форме, значења и синтаксичке функције коју обављају. ${ }^{3}$

\section{2. Теоријски оквир}

Различитим дефиницијама фразеологизама у литератури заједничко је то да се описују као релативно чврсти вишелексемски спојеви, који се у говору репродукују као целина устаљена употребом, чије значење није једнако збиру значења њених појединачних елемената, већ елементи у споју изражавају јединствено значење, те као целовита лексичка јединица могу обављати неку синтаксичку функцију (в. Menac 1979: v; Matešić 1982: 6; Мршевић Радовић 1987: 13; Prćić 2016: 161). Код фразеологизама с формом глаголско-именичке синтагме, чији је удео у нашем корпусу значајан, може се извршити подела на основу типа детерминације међу компонентама синтагме на глобалне фразеолошке јединице (нпр. обрати зелен бостан) у којима су компоненте међусобно зависне и фразеологизирана је читава синтагма (Мршевић Радовић 1987: 13-14) и компонентне фразеологизме, у

\footnotetext{
2 Речници ће у даљем тексту по потреби бити обележени скраћеницама, редом: JМ, ЂО, РМС и РСАНУ.

3 На сличан начин обрађени су фразеологизми који обележавају емоционалне концепте у раду Морфосинтаксичка обележја фразеологизама у српском језику (Драгић 2017), при чему се у том случају при одабиру јединица пошло од значења, док овде полазимо од порекла и садржаја нефразеолошке синтагме, што подразумева појаву различитих значењских домена.
} 
којима је именица носилац фразеолошког значења, док глагол у њему не учествује иако је део структуре израза (Мршевић Радовић 1987: 14). Именички конституент компонентног фразеологизма има функцију квалификатора или интензификатора у односу на значење глагола (нпр. не вреди ни зрна боба 'ништа, нимало не вреди') (Мршевић Радовић 1987: 14).

У својој монографији Српска фразеологија и религија Н. Вуловић објашњава религијску компоненту у фразеологизму као лексему, најчешће именицу, која „може означавати различите религијске појмове (овде спадају по категоријалној припадности компоненте и придеви или прилози изведени од именица) или религијско-обредне радње (најчешће глаголи), [...]" (Вуловић 2015: 39). Угледајући се на поделу коју ова ауторка наводи, у корпусу смо идентификовали религијске компоненте које обележавају библијске и религијско-историјске личности (Адам, Ева, Понтије Пилат и сл.), духовна (трансцендентна) бића или духовно посвећене особе (бог, ђаво, анђео и сл.), појмове везане за религијску и црквену праксу и теорију (критење, грех и сл.), религијске предмете (крст, тамјан и сл.), као и топониме из Библије (Содома и Гомора) (в. поделу Вуловић 2015: 39). Фразеологизмима религијског порекла сматраћемо, поред оних с религијском компонентом, и оне који одговарају ширем појму библизма. Такви изрази потичу из Светог писма иако не садрже религијску компоненту схваћену у најстрожем смислу, попут примера блудни син и забрањено воће.

\section{2. Анализа}

Фразеологизме ћемо у раду најпре разврстати према граматичкој структури, по угледу на Н. Вуловић, која је у својој монографији граматичким описом обухватила и неке од фразеологизама које наводимо у

4 Библизмима се сматрају „различите структурно-семантичке језичке творевине, устаљени изрази, фразеолошке јединице, цитати, терминолошке синтагме, који могу бити преузети директно као готове форме из Библије или могу настати под утицајем алегорија, парабола, догађаја описаних у Светом писму, али могу потицати и из хришћанског предања" (Мокијенко 2011: 674, према Вуловић 2015: 35). Фразеолошке и афористичне јединице које потичу из Библије или су настале на њеној основи (попут алфа и омега и сл.) називају се директним библизмима, док се оне засноване на представама, на перцепцији догађаја или личности из Библије у човековој свести (попут шаљиве форме $y$ Адамовом костиму) називају индиректним, посредним библизмима (Валтер 2009: 74-75 према Вуловић 2015: 35). 
раду (Вуловић 2015: 80-84), а затим описати њихово понашање у синтаксичком контексту. У погледу структуре, региструјемо четири главна типа израза: фразеологизми са структуром именичке конструкције, односно синтагме; фразеологизми са структуром глаголско-именичке конструкције, односно синтагме; фразеологизми са структуром предлошко-падежне конструкције и фразеологизми са структуром реченице.

\section{1. Фразеологизми са структуром именичке конструкције}

У ову групу, која је и најбројнија од наведене четири, спадају изрази у којима се именица јавља као управна реч. Изрази из ове групе, у складу са својом структуром и значењима, заузимају различите синтаксичке позиције. Будући да су претежно у питању семантички еквиваленти именица, а структурно именичке конструкције, махом заузимају позиције субјекта, директног објекта и лексичког дела копулативног или семикопулативног предиката, те семантичког центра перифрастичног (декомпонованог) предиката. Посебне коментаре уз примере наводићемо тамо где у неком погледу постоје одступања од оваквог синтаксичког понашања.

2.1.1. Именичко-придевска конструкција: именичка синтагма - именица + придев / придев + именица

Ови спојеви представљају фразеологизме у којима делови заједнички конституишу фразеолошко значење, док се на нефразеолошком, синтагматском плану у саставу ових конструкција углавном јављају описни, релациони и присвојни придеви као конгруентни атрибути: смоквин лист 'оно чиме се покрива каква срамота' или 'средство за прикривање (лажне) срамоте'; Нојева барка 'мноштво (различитих) људи на малом простору' / 'средство спасења'; цүарство божје 'загробни живот и уживање у њему, рај, небо'; вавилонска кула 'збрка, хаос, метеж'; ватрено критење 'прво искуство, учествовање у каквој борби, у великом искушењу'; неверни Тома 'онај који не верује, који сумња у све, сумњичав, скептичан'; источни грех

5 Форме фразеологизама и њихова значења дата су на основу наведених фразеолошких и општих речника, у појединим примерима на основу навода из стручне литературе, с настојањем да се различите варијанте израза и значења обједине у сврху једноставнијег приказа. То је у неким случајевима условило незнатне модификације у односу на приказе у појединим изворима. 
'а) цркв. грех који се не може искупити; б) велика мана, порок, поступак, дело које се не може опростити'; смртни грех 'тежак преступ'; жртвено јагње 'онај на кога се баца сва кривица', односно 'човек на кога се сваљује туђа кривица'; забрањено воће 'нешто што се воли, али се не сме уживати'; обећана земља 'срећна/богата земља или место, рај у идеалном или материјалном смислу'; блудни син 'човек који је у животу пошао погрешним, лошим путем'; бич божји 'божја казна, велико зло, несрећа'; хлеб насушни 'оно што је најважније/преко потребно за живот'; вартоломејска ноћ 'крвопролиће, покољ'. Изузетак је фразеологизам соломонско решење 'мудро, праведно, довитљиво решење (којим су обе стране задовољне)', у коме је управо придев носилац фразеолошког значења, док именица решење задржава своју примарну семантику што се одражава и на начин његовог прилагођавања контексту. Придев соломонски овде значи 'мудро, праведно, довитљиво', те на исти начин детерминише именицу и у варијанти соломонска одлука. При уклапању у контекст тако је омогућено формално раздвајање чланова синтагме, те њено трансформисање у клаузу као у примеру: Ако би одлука била соломонска [...]; у којој именица одлука онда попуњава функцију субјекта, док се придев помера на позицију лексичког дела копулативног предиката. У примеру [...] изнашао je лидер ПС-а соломонско решење [...] фразеологизам се појављује као допуна глагола у декомпонованом предикату, где је именица решење експонент дубинске предикације - процеса, који је фразеолошким значењем придева детерминисан у погледу начина. Као атрибутив се јавља читав израз блудни син (блудни син Леброн). Изрази код којих нефразеолошка синтагма (и значење) подразумева просторни појам јављају се често на позицији просторног адвербијала, унутар предлошко-падежне конструкције ([...] дошла ,у ияарство божије”; [...] повести друштво у ,обећану земљу”,).

[...] обожаваоции су били одушевљени, док се по који неверни Тома смешио из прикрајка (И261116 $)$; 3 абрањено воће је

\footnotetext{
${ }^{6}$ Скраћеница И односи се на примере преузете из електронских бројева Политике пронађених на интернету, а $K$ на примере преузете из Корпуса Математичког факултета. Нумеричке шифре означавају датум објаве чланка - прве две цифре означавају дан, друге две месец, а треће годину.
} 
најслађе, [...] (И310814); Математички поглед на језике можда гради вавилонску кулу уз помоћ рачунара [...] (К300106); Партизанови рукометаши су успешно пребродили ватрено критеюе на старту сезоне [...] (К221000); Ако тај експресивни „источни грех” Николића разумемо као акутни излив јаких емочија, [...] (К140507); Сан Марко је Нојев а барка у којој, без приоритета и изузимања, има места за све, [...] (И070809); [...] како неко да буде бич божји тржишне економије, ако сваки дан пуни новинске ступце [...] (К070908); Ништа није постигнуто акредитацијом, која се свела на пуку формалност и постала „сммквин лист” за неке универзитете (К030910); 3 а „ж жтвено јагње " изабран је Хитлеров „лични пријатељ”" Вислени, [...] (К231100); Ако би одлука била соломонска и свакој страни омогућила да тражи аргументе за себе [...] (И140710); [...], изнашао је лидер ПС-а соломонско решење, које би укључивало, ваљда, и рушење кадра юегове партије [...] (И221216); Имала је, каже, 13 година када је дошла „у ца ар ст во божије" (И050812); Излаз из неизвесности се тражи y јаком вођи који ће повести друштво у ,обећану з емљу"'(К280401); [...] у ноћи између среде и четвртка, када се ,, блудни син” Леброн бар на кратко врати кући [...] (К021210); Српска „В артоломејска ноћ” није довела до промене закона, политике и односа према другима (И180320); Научнички хлеб насушни (И271008).

\subsection{2. Именица + именица у зависном падежу}

У нашим примерима се као зависни падеж јавља генитив као неконгруентни атрибут: камен спотицања 'главна тешкоћа у остваривању чега', камен смутње 'узрок или повод свађе, односно раздора'.

Највећи камен спотицањ а јесте новаи, односно питање ко ће сносити трошкове замене марке у евро (К100800); [...], а ми тиме остављамо камен смутье генерацијама које долазе” (И230110).

\subsection{3. Именица + именица у номинативу}

Друга именица у номинативу на синтагматском плану представља именички атрибут, односно атрибутив у односу на прву у изразима звезда 
водиља 'оно што некога води у животу; путоказ'; анђео чувар 'заштитник уопште, бранитељ, онај који бдије над животом'.

Тета Маргита је ово заслужила на нарочит начин, била је ан ђе о чув ар наше породице... (И2262014); Ауторитарна воља за моћ не треба да буде нашаз в ез да водиља (К071100).

2.1.4. Напоредна именичка синтагма - именица у номинативу $+u+$ именица у номинативу

Фразеологизам алфа и омега, са значењем 'почетак и свршетак', у контексту увек захтева допуну у генитиву, с којим у неким примерима врши функцију именичког атрибута, односно атрибутива уз властите именице. Овде спада и израз Содома и Гомора 'разврат, велика поквареност, пропаст'.

Ову тему је помпезно, у свом стилу, покренуо „, алфа и омега" загребачког Динама Здравко Мамић (К220210); [...] ови их ни не питају за доказе, нити проверавају податке, иако су то алфа и омега журнализма” (К101200); Содома и Гомора у Лондону - краљ је именован, а његов љубавник добија све веће и веће титуле (И141217).

\section{2. Фразеологизми са структуром глаголско-именичке конструкције}

\subsection{1. Глагол + именица/именичка синтагма у зависном падежу без предлога}

У овој групи налазе се глобални фразеологизми у којима се именица или именичка синтагма с обавезно исказаним атрибутом јавља као допуна прелазног глагола у акузативу без предлога, односно као његов формални објекат: бацити ${ }^{7}$ (ударити) анатему ${ }^{8}$ (на кога/шта) 'проклети кога или шта';

7 Глаголи у нефразеолошкој синтагми и у оквиру значења навођени су само у свршеном или несвршеном виду према томе који се чешће појављује у речницима и примерима, што не искључује могућност појаве другачијег видског облика у тексту.

8 Према Појмовнику српске културе доступном на сајту Етнографског института САНУ, анатема је грецизам са основним значењем 'искључење, удаљавање (из дотадашње средине)', 'проклетство' (Тодоровић, Павићевић 2016). РСЈ под одредницом анатема као прво значење наводи 'а. искључење из верске заједнице; проклетство јеретика које изриче црква искључењем из верске заједнице', а под б. се наводи, уз ознаку фиг. и разг., 'клетва, оштра осуда, укор'. Сам израз бащитии 
скинути светитељски/светачки ореол (коме) 'разголитити, приказивати шта без лажнога сјаја'; носити свој крст 'подносити тешке патње, живети под теретом велике муке и невоље; имати злу судбину'; прати (умити) руке [као Пилат] $]^{9}$ 'скинути са себе одговорност'. Забележена су и два израза у којима је глаголска допуна у инструменталу: крстити се и левом и десном [руком] 'јако/много се чудити', посипати се пепелом [по глави] 'кајати се због учињених недела; јавно показивати кајање због учињеног'. Инструментал је у првом примеру објекатска допуна глагола којом се обележава орган, који се заједно с агенсом, чији је део, покреће при вршењу радње кретања (Антонић 2005: 244). Инструменталном допуном у другом случају на нефразеолошком плану обележава се средство, спроводник који је појамматерија (Антонић 2005: 262). Међу прикупљеним примерима забележене су промене у лексичком саставу, па и значењу и синтаксичком понашању израза - тако је, нпр. регистрована само форма скинути анатему, коју не бележи ниједан од коришћених речника. Варијанта с глаголом који у овом контексту читавом фразеологизму даје антонимично значење у односу на оригинални облик, мења и обавезно контекстуално окружење фразеологизма из ППК с адлативним акузативом (на кога/шma) у ППК с аблативним генитивом ( $c$ кога/чега). Будући да сви изрази из групе обележавају радње или емотивне процесе, очекивана је и потврђена њихова употреба на позицији предиката, а пошто су синтаксички регирани глаголима, по правилу отварају место за реализацију субјекта у номинативу, осим када се појаве у оквиру сложеног предиката с безлично употребљеним глаголом требати и сл. Уз израз крстити се и левом и десном као еквивалент глагола чудити се обично се у реченици експлицира и каузатор стања (у нашем примеру у форми клаузе).

Треба скинути анатему са Савезне изборне комисије [...] (К051000); Тим поистовећивағем наводно великих револуционара са обичним друмским разбојницима Милошевић им је скинуо

анатему наводи се као пример употребе за прву нијансу значења, док је значење фразеологизма наведено у тексту рада пронађено у Фразеолошком рјечнику Јосипа Матешића.

${ }^{9}$ У угластим заградама наведени су елементи који се наводе у неким речницима, али се у примерима обично не појављују, те стога дате фразеологизме сврставамо у структурни модел којим обележени конституенти нису обухваћени. 
светитељски ореол са главе, [...] (И170207); Али свако носи свој крст (И101108); Стога, није чудно да сада,, пере руке” убеђујући друге наоколо како је Југославија била грешка [...] (К301108); А ја баш и нисам показивао превише склоности да се посипам пепелом због некадашњих мојих веза с Београдом, [...] (К171007); [...] да су се [...] представниции једне од светских финансијских институција крстили и левом и десном руком ита смо урадили са Међународном професионалном регулативом [...] (И090214).

2.2.2. Глагол + именица у зависном падежу + предлошко-падежна конструкција

Фразеологизам отићи (ићи, одлетети, вратити се, поћи) богу на истину има значење 'умрети, преминути'. Нефразеолошка синтагма садржи датив с обележјем адлативности и предлошки акузатив са значењем намере, циља, те читав неглаголски део конструкције у односу на глагол има функцију адвербијалне одредбе, док се израз у примерима јавља у функцији предиката. У структури фразеологизма ставити руку y ватру (за некога) 'јамчити, гарантовати (за некога)' прелазни глагол допуњен је беспредлошким акузативом као формалним објектом, након чега следи адлативни акузатив с предлогом $y$, док се допуна за + акузатив региструје само у неким примерима у којима се израз преко ње уклапа у контекст на позицији предиката. Када се израз реализује без ове допуне, може за себе везати објекатску клаузу.

У народу се за угледну личност, при растанку са овоземаљским животом обично каже: „О Отишао Богу на истину” или „Мијенио свијет” (К021209); [...] , али сада више нико „не сме да став и руку у ват ру ”да та већина још постоји [...] (К181007); Прави пријатељ ће, кажу, „ставити руку у ватру”за nријатеља (И150811). 


\subsection{3. Глагол + предлошко-падежна конструкција}

Фразеологизми провући (се)/проћи кроз иглене уши '10 'једва, уз много тешкоћа, уз велике напоре постићи нешто, остварити нешто готово немогуће; једва се спасити' (ЂО); шетати од Понтија до Пилата 'тражити, лутати са каквим циљем, обијати прагове'; ићи/отићи доврага/дођавола 'пропасти' у нефразеолошкој основи садрже ППК просторних значења компатибилних са значењима глагола уз које стоје (просекутивно, аблативно-адлативно и адлативно). Сва три израза су семантички еквиваленти глагола, што је у складу и с њиховом граматичком структуром, те се употребљавају на синтаксичкој позицији предиката. Последњи израз у наведеном низу формално представља глаголску синтагму с прилогом као зависним чланом, али се и из речничких дефиниција види да су прилози дођавола/доврага настали срастањем адлативне ППК до + генитив (тако нпр. РМС и РСАНУ бележе форме до ђавола). Последњи израз из ове групе, забележен у само једном примеру, јесте фразеологизам мирисати на тамјан 'преживљавати последње дане, приближити се смрти, бити близу смрти / при крају живота', у коме уз глагол у нефразеолошкој синтагми стоји конструкција на + акузатив.

За то време је мој предмет иетао од Понтија до Пил а т а , све док на крају није завршио на почетку, [...] (К051200); Лањски победник Налбандијан прошао је кроз иглене уши (К161106); Провукла се кроз иглене уши, спасивши у том узбудливом дуелу од безмало три и по часа и две меч-лопте (К280608); Када све оде доврага - што се повремено дешава финансијски гуруи подсећају да се у свему што су саветовали [...] (К120201); E, па кад је тако, мислио сам, нека и роман као форма иде дођавола (К160607); Све је то старо изнемогло српство мирисало на тамјан ${ }^{11}$ (И150217).

\footnotetext{
${ }^{10}$ Овај фразеологизам има већи број верзија које зависе од употребљеног глагола, али само су наведена два потврђена у примерима.

11 Овај чланак, иако формално из 2017, заправо је поновљени текст Милоша Црњанског објављен у листу Политика на Бадњи дан 1925. године.
} 


\subsection{4. Глагол + поредбена конструкција}

У овој групи налазе се фразеологизми бежати (зазирати, уклањати се) (од кога, од чега) као враг/Ђаво од крста (свеће, тамјана), бојати се (чувати се) кога/чега као враг тамјана, за које се наводе готово иста значења: 'избегавати сваки додир или сусрет, зазирати од кога, од чега, избегавати шта, не трпети, не подносити кога, шта'; коштати (стајати) (кога) као светог Петра кајгана 'коштати (некога) врло скупо'. Они спадају у групу компонентних фразеологизама, у којима глагол задржава своје основно значење, док је поредбена конструкција носилац фразеолошког значења и представља кондензовану, редуковану начинску (поредбену) клаузу (бојати се кога, чега као што се враг боји тамјана; коштати некога колико је коштала светог Петра кајгана), служећи као интензификатор значења глагола (делимично описано у Драгић 2017: 104). Предлошки или беспредлошки аблативни генитив у нефразеолошкој синтагми прва два израза упућује на каузатора процеса, реализујући се паралелно и у првом делу као обавезно окружење којим се фразологизам укључује у синтаксички контекст, док сам глагол отвара и место за субјекатски појам са обележјем персоналности. Слично је и у последњем изразу, ${ }^{12}$ где поредбени део служи као обавезни додатак са значењем квантитета, док се као обавезно окружење јавља беспредлошки акузатив који упућује на носиоца ситуације. Граматички субјекат у овом случају ће обележавати неживи појам, а читав фразеологизам, као и претходна два у овој групи, има значење управног глагола, с акцентом на интензитету односно квантитету, који је исказан фразеологизираним делом структуре. Изрази махом врше предикатску функцију, некада самостално, а некада као делови сложених предиката уз модалне, модалитетне и фазне глаголе.

12 Дати израз је двозначан и постоје два могућа објашњења његовог настанка у народним причама и стручној литератури на основу којих се облик светог Петра може тумачити на два различита начина. Према првом тумачењу, закључује се да се ради о кајгани која је била намењена светом Петру, а некога другог је скупо коштала (Шипка 2010: 97), те је у овом случају као граматички облик присутан генитив. С друге стране, постоји и објашњење засновано на народној причи према којој је Свети Петар, боравећи у нечијој кући, појео туђу кајгану (Шипка 2010: 97-98), па бисмо у случају прихватања ове верзије облик светог Петра морали тумачити као акузатив. 
... лоше мисли беже од хумора као ђаво од тамјана (К190109); Глупсе човекбоји књиге као ђаво одкрста (И020310); [...] строги центар Осла - где изградња иркве или адаптирање неке зграде у божији храм кошта као „, ветог Петра кајгана" (К171108); [...] као и са хулиганством, где нас је подражавање већ превише пута коштало као светог Петра кајгана (К020909).

\section{3. Фразеологизми са структуром предлошко-падежне конструкције}

У овој групи налазе се фразеологизми који на структурном плану представљају спој предлога и именице или именичке фразе у зависном падежу - на силу бога 'неправедно, без правога разлога, силом' и $у$ Адамовом/Евином костиму 'го(ла), наг(а), без одеће'. Последњи фразеологизам има две варијанте (истог значења) у зависности од библијског антропонима из кога је изведен присвојни придев употребљен у функцији конгруентног атрибута уз именицу костим, која се налази у локативу. Први израз има прилошко значење, које се у зависности од контекста може тумачити као допусно, начинско или узрочно, у складу с којим се и употребљава на позицији авдербијала, што је у извесној мери у нескладу с његовом структуром којом не управља прилог као примарни облик изражавања адвербијалних значења. Други израз је семантички еквивалент придева и обично се јавља у функцији атрибута (често предикативног).

Британије што се тиче, она је - ако ме памћење не вара - у ЕУ врло нерадо, такорећи на силу Бога ушла, у ЕУна силу Бога била, али из ЕУ није изашла на силу Бога... (И270615); Све више туриста у „Адамов ом костиму” се скија, шета и пентра по планинама у Словенији (К290909); [...] кьижевница и филмска сиенаристкиња Мануела Гретковска, сликала се у Евином ко с ти м у, [...]” (К240907).

\section{4. Фразеологизми са структуром реченице}

У овој групи налазе се фразеологизми чији је основни структурни лик, забележен у речницима, облик реченице, при чему се од фразеологизама са структуром глаголско-именичке синтагме разликују у томе што потоњи постају реченице, односно предикати тек стављањем фразеологизма у контекст, а глагола који му је у саставу у лични облик (Menac 2007: 18, 19). 
Фразеологизми овакве форме обично имају недовршену, отворену структуру и често су у питању елидиране реченице будући да је потребно да бар један конституент буде зависан од окружења како би се фразеолошка јединица могла употребити у контексту (Вуловић 2015: 83).

\subsection{1. Независна реченица}

У ову групу спадају изрази бог (свети) зна, бог зна кад (зашто, где и сл.), бог те пита када (ита, колико, како, зашто, и др.), бога питај, у чијим је значењима активирана заједничка компонента 'не зна се, неизвесно је, нико не зна' (Вуловић 2015: 242), као и изрази враг/ђаво би га знао / враг/ђаво ће га знати 'ко зна, немогуће је знати, објаснити', док шаљиви фразеологизам nутуј, игумане! !3 има значење 'ниси неопходан' (Вуловић 2015: 171). На нефразеолошком плану, лексеме бог и Ђаво/враг појављују се на позицији субјекта, изузев у изразу бога питај где је именица бог објекат транзитивног глагола у императиву. Императив је, уз именицу у вокативу, употребљен и у фразеологизму путуј, игумане. У преосталим изразима с лексемом бог употребљава се презент, док се у различитим варијантама израза с лексемом враг/Ђаво може појавити потенцијал или футур 1. Објекат се реализује у форми заменице унутар основне структуре два израза (бог те пита, Ђаво ће га знати), али сви они отварају место за објекатску допуну исказану (упитним) прилозима, предлошко-падежним заменичким конструкцијама с упитним заменицама или зависноупитном клаузом која их укључује у контекст. У неким случајевима та допуна забележена је у речнику, док у другима није, иако се у примерима редовно реализује уз све изразе. Унутар сложене реченице ове клаузе функционишу као независне, често на управној позицији у односу зависне допунске клаузе.

Јако много докумената је протеклих година проглашавано за тајне, бог зна зашто (К020309); Данас су овде, сутра тамо, а докле: бог свети зна (К190201); [...], али по мом мишљену то није

\footnotetext{
${ }^{13}$ Н. Вуловић овај фразеологизам смешта међу јединице са структуром глаголскоименичке синтагме - глагол у императиву + именица у вокативу (Вуловић 2015: 83). Будући да је у основном облику овог израза ипак употребљен лични глаголски облик, те да се он не може превести у инфинитив, ми га ипак сврставамо међу фразеологизме са структуром реченице.
} 
тачно, питај бога ко је већински власник (К091209); Данас када се вратим унатраг и погледам кроз шта смо све прошли (а бог те пита ита нас још очекује), чини се да [...] (К020808); Власнику радюе име и почетно слово презимена, ђаво ће га знати због чега, кад су дати сви остали подаци, па и адреса златаре... (К171208); [...], али шта је овај хтео, враг би га з нао (К300706); [...] када се накупило радне снаге коју није имао где да запосли, поделио пасоше и рекао: „Путуј, игумане!” (И140917).

\subsection{2. Зависна реченица}

У овој форми појављују се изрази како бог заповеда 'како ваља, како треба, добро, пристојно, у реду', где је бог рекао лаку ноћ 'веома далеко, у забаченом крају, месту, далеко од цивилизације, у недођији'. Први наведени фразеологизам има форму зависне начинске клаузе уведене прилошким везником како, с предикатом у презенту. Други фразеологизам има облик релативне прилошко-детерминативне клаузе и уводи га прилог односно прилошки везник где, уз прелазни глагол у перфекту и допунску конструкцију лаку ноћ у акузативу. У оба случаја лексема бог заузима позицију субјекта. Први фразеологизам се у примерима употребљава у складу са својим значењем и формом, као адвербијал за начин, док други израз функционише као атрибутска клауза с антецедентом месног прилошког значења - прилогом или предлошко-падежном конструкцијом.

Да бисмо на бини свирали како бог за поведа морамо довољно пива да попијемо, [...] (К160609); Бенадићи и Илинчићи желе да буду кумови како Бог заповеда, и зато дуго трају [...] (И171215); [...] тамо где је бог рекао лаку ноћ (И150312); Стизала сам украјевегде је Бог рекао „лаку ноћ”, [...] (И160207).

\section{3. Закључак}

Узимајући у обзир спроведену анализу, закључујемо да међу испитаним фразеологизмима религијског порекла према структурном типу доминирају изрази у форми именичке конструкције (односно синтагме), те у овој групи бележимо чак 22 примера, од којих чак 16 има облик именичке синтагме с придевским конгруентним атрибутом. Велика заступљеност и учесталост употребе израза оваквог устројства разумљива је будући да се они, 
захваљујући једноставној форми, без већих структурних модификација могу употребити на готово свим синтаксичким позицијама само пребацивањем у одговарајући падежни облик. Захваљујући томе, иако су махом семантички еквиваленти именица и именичких синтагми, они ипак у одређеним контекстима могу исказивати и прилошка значења и заузимати одговарајуће синтаксичке позиције поред позиција субјекта, директног објекта и семантичког центра копулативног, семикопулативног или декомпонованог предиката у којима се најчешће срећу. Мора се напоменути и да је веза фразеологизама из дате групе са Светим писмом најчешће директна, што омогућава релативно једноставно откривање порекла те објашњава донекле њихову бројност у студији од које се у прикупљању израза пошло. Бројна је и група фразеологизама са структуром глаголско-именичке конструкције те са структуром реченице, при чему се изрази из ових и осталих структурних типова готово у свим примерима употребљавају на синтаксичким позицијама које одговарају њиховој морфосинтаксичкој структури и особинама њихових конституената, што указује на висок степен компатибилности граматичког садржаја нефразеолошке синтагме и фразеолошког значења. Остале граматичке форме фразеологизама, због саме сложености структуре, компликованијег процеса укључивања у синтаксичко окружење те специфичности значења (нпр. искључиво начинско или временско прилошко значење), ограничене су на мањи број граматичких функција.

Употреба фразеологизама религијског порекла у медијском дискурсу је жива и они се релативно учестало појављују у новинским текстовима при обради широког спектра тема задовољавајући критеријуме експресивности и информативности захваљујући препознатљивости форме и поруке коју она сликовито преноси. Будући директно или индиректно повезани с библијским текстом, овакви изрази омогућавају ефектно изражавање коментара различитих друштвених прилика остварујући у свести читалаца контакт с хришћанским наслеђем и подразумеваним системом вредности чија се исправност не доводи у питање. Таква њихова употреба у многим случајевима повећава убедљивост и перципирану оправданост става који се датим изразима потенцира, имплицитно се позивајући на колективна знања и искуства која се огледају у фразеологији. 


\section{И З В О Р И}

Оташевић, Ђорђе (2012). Фразеолошки речник српског језика. Нови Сад: Прометеј.

PMC: Речник српскохрватскога књижевног језика, I-III. Нови Сад - Загреб: Матица српска -Матица хрватска, 1967-1969. IV-VI, Нови Сад: Матица српска, 1971-1976.

РСАНУ: Речник српскохрватског књижевног и народног језика, I- . Београд: САНУ, Институт за српски језик САНУ, 1959- .

Matešić, Josip (1982). Frazeološki rječnik hrvatskoga ili srpskog jezika. Zagreb: Školska knjiga.

\section{ЛИТ Е Р А Т У Р А}

Антонић, Ивана (2005). Синтакса и семантика падежа. У: Пипер, Предраг и др. (2005). Синтакса савременога српског језика. Проста реченица. Београд: Институт за српски језик САНУ, 119-344.

Вуловић, Наташа (2015). Српска фразеологија и религија. Београд: Институт за српски језик САНУ.

Драгић, Мила (2017). Морфосинтаксичка обележја фразеологизама у српском језику. Прилози проучавању језика, бр. 48: 93-107.

Мршевић Радовић, Драгана (1987). Фразеолошке глаголско-именичке синтагме у савременом српскохрватском језику. Београд: Филолошки факултет.

Тодоровић, Ивица и Александра Павићевић (2016). Анатема.

<http://etno-institut.co.rs/cir/pojmovnik/a/anatema.php>

Шипка, Милан (2010). Зашто се каже? Нови Сад: Прометеј.

$*$

Menac, Antica et al. (1979). Rusko-hrvatski ili srpski frazeološki rječnik. Zagreb: Školska knjiga.

Menac, Antica (2007). Hrvatska frazeologija. Zagreb: KNjIGRA.

Prćić, Tvrtko (2016). Semantika i pragmatika reči, treće, elektronsko izdanje. <http://digitalna.ff.uns.ac.rs/sadrzaj/2016/978-86-6065-356-9> 
Mila Dragić

MORPHOSYNTACTICAL CHARACTERISTICS OF PHRASEOLOGISMS OF RELIGIOUS ORIGIN IN SERBIAN LANGUAGE

\section{SUMMARY}

This paper examines the morphosyntactic characteristics of Serbian phraseologisms of religious origin as well as the compatibility of their form, meaning and syntactic function when used in journalism. The corpus consists of approximately 50 phraseologisms of religious origin with different meanings. Phraseologisms are grouped according to structure, and it is concluded that nominal phrase is the dominating form, while most units are used in syntactic positions that correspond to their formal (and semantic) properties.

KEYWORDS: phraseology, phraseologisms, religious origin, morphosyntax, structure, function.

Мср Мила Драгић

Одсек за српски језик и лингвистику

Филозофски факултет, Универзитет у Новом Саду

Србија

mila.dragic@ff.uns.ac.rs 
